\title{
Rancang Bangun Media Interaktif Untuk Kerajinan Tangan Tradisional
}

\author{
Tonny Hidayat \\ Teknik Informatika STMIK AMIKOM Yogyakarta \\ E-mail: tonny hank@amikom.ac.id
}

\begin{abstract}
Abstrak
Teknologi di era globalisasi memegang peranan yang sangat penting dalam kemajuan sebuah perusahaan baik untuk tujuan marketing atau untuk tujuan promosi sebuah produk atau jasa, maupun untuk tujuan lainnya seperti pemanfaatan teknologi sebagai alat bantu atau media pembelajaran di dalam dunia pendidikan. Salah satu perkembangan teknologi yang mengalami pertumbuhan pesat saat ini adalah teknologi multimedia. Teknologi multimedia adalah salah satu bentuk teknologi informasi yang menggabungkan (integrasi) gambar, tulisan, suara, video, animasi, menjadi sebuah aplikasi informasi yang interaktif dan menarik, sehingga dapat digunakan sebagai alat untuk menyampaikan sebuah informasi.Kerajinan Mendong adalah sebuah kerajinan tangan berupa anyaman dari tanaman mendong yang dikresikan menjadi sebuah tas, dompet, tikar dan masih banyak hasil lainnya. Kerajinan ini merupakan sebuah komoditi local terutama di daerah Jawa Tengah yang harus di lestarikan dan dibudidayakan. Perlunya penyebaran informasi dan budidaya serta pengetahuan tentang kerajinan mendong ke masyarakat dan siwa sekolah.Pemanfaatan aplikasi Media Interaktif terhadap kerajinan tangan ini dapat menjadi informasi serta pengetahuan bagi masyarakat umum dan menjadi menjadi penarik minat masyarakat untuk menjadi pengrajin dan mengembembangkan kerajinan mendong. Dengan media ini akan memberikan pendekatan baru untuk media pendidikan yang ada saat ini, bukan hanya menggunakan real objek tetapi juga dapat digunakan keberbagai bentuk obyek dalam penyampaian informasi.
\end{abstract}

Kata Kunci - Media Interaktif, Multimedia, Kerajinan

\begin{abstract}
Technology in the era of globalization plays a very important in the progress of a good company for marketing purposes or for the purpose of promotion of a product or service, or for other purposes such as the use of technology as a tool or medium of learning in the world of education. One of the technological developments experienced rapid growth at this time is a multimedia technology. Multimedia Technology is one form that combines information technology (integration) images, text, sound, video, animation, become an interactive application and exciting information, so it can be used as a tool to convey information.Mendong Crafts is a crafts such as woven from plants that dikresikan rushes into a bag, purse, mats and many other results. This craft is a local commodity, especially in the area of Central Java, which should be preserved and cultivated. The need for the cultivation and dissemination of information and knowledge about the craft rushes to the school community and Siwa.Utilization of Interactive Media applications against these crafts can be information and knowledge for the general public and be be towing the public interest to be artisans and crafts mengembembangkan mendong. With this medium will provide a new approach to media education that exists today, not only using real objects but also can be used every aspect of the shape of the object in the delivery of information.
\end{abstract}

Keywords - Interactive Media, Multimedia, Craft 


\section{PENDAHULUAN}

Di zaman modern dan serba instan seperti saat ini, produk kerajinan dapat menjadi penyeimbang pertumbuhan zaman dan arus modernisasi. Di tengah ketakutan penduduk bumi dengan ancaman global warming atau sering disebut dengan pemanasan global yang semua itu disebabkan karena pencemaran lingkungan seperti limbah plastik, limbah logam dan lain sebagainya, produk kerajinan yang berbahan dasar alami dan ramah lingkungan akan menjadi suatu produk yang menjanjikan baik untuk pasar domestik maupun pasar global.

Pandangan mayoritas masyarakat Indonesia yang menganggap bahwa suatu produk hasil olahan tangan (handmade) harganya dibawah produk olahan mesin adalah suatu kendala yang sedikit banyak mempengaruhi posisi harga suatu produk kerajinan tangan di pasar. Namun lambat laun pemikiran itu akan berubah mengikuti perkembangan zaman bahwa manusia tentu jauh lebih baik dan berharga jika dibandingkan dengan mesin.

Agar suatu produk kerajinan tangan dapat terus bertahan di tengah era perdagangan bebas yang kian kompetitif, maka diperlukan upaya untuk terus melestarikan produk kerajinan tangan tersebut dari suatu generasi ke generasi berikutnya sebagai bentuk keterampilan yang berkembang secara turun-temurun. Upaya pelestarian produk kerajinan tangan dapat dilakukan dengan berbagai cara, salah satunya dengan memanfaatkan teknologi multimedia yang informatif, mudah dipahami, interaktif dan menarik sebagai media pembelajaran agar dapat ditiru oleh generasi-generasi berikutnya. Teknologi multimedia ini dapat digunakan sebagai media untuk menyampaikan informasi tentang sejarah kerajinan, bahan-bahan yang digunakan, metode pembuatannya, sampai dengan hasil akhir produk dengan berbagai ragamnya. Pemanfaatan teknologi multimedia ini dapat disesuaikan dengan usia generasi yang akan mempelajarinya. Dalam penelitian ini, perancangan teknologi multimedia sebagai media pembelajaran pembuatan kerajinan mendong, secara khusus dirancang untuk usia generasi setingkat SMP/SMA. Berdasarkan uraian di atas, penulis akan merancang sebuah aplikasi berbasis multimedia interaktif sebagai media pembelajaran pembuatan kerajinan Mendong.

Teknologi aplikasi multimedia mencakup bidang-bidang yang cukup luas, namun dalam penelitian tugas akhir ini, penulis membatasi pada hal-hal sebagai berikut:

a. Media pembelajaran ini hanya terbatas pada pembuatan kerajinan Mendong.

b. Media pembelajaran ini hanya ditujukan pada usia generasi setingkat SMP/SMA.

c. Teknologi multimedia yang digunakan adalah teknologi animasi 2 dimensi.

d. Perangkat lunak utama untuk membangun aplikasi multimedia interaktif ini adalah Adobe Flash.

Perancangan untuk merancang suatu teknik animasi yang menarik, informatif, mudah dipahami, serta interaktif sebagai media pembelajaran pembuatan kerajinan mendong dengan teknik anyam, khususnya ditujukan kepada mereka atau generasi setingkat SMP/SMA yang ingin mengetahui dan mempelajari tentang teknik pembuatan kerajinan mendong.

Pada penelitian ini yang akan dijadikan sebagai objek penelitian adalah sebuah kerajinan mendong, yang merupakan sebuah kerajinan dari masyarakat Indonesia. Mendong dengan nama latinnya adalah Fimbristylis Globulosa adalah salah satu tumbuhan yang hidup di rawa. Tanaman ini tumbuh di daerah yang berlumpur dan memiliki air yang cukup, masih dalam kategori jenis tanaman rumput dan tumbuh dengan panjang kurang lebih $100 \mathrm{~cm}$. Kerajinan mendong sudah lama dikenal masyarakat mulai dari tikar, tempat pensil, dompet, tempat sampah, tempat toples, tas,dan lain sebagainya. Namun industri kerajinan ini, dalam perjalanannya harus bersaing dengan industri kerajinan berbahan plastik.

Untuk pengembangan bidang usaha kerajinan mendong maka banyak dilakukan upaya antara lain perlu dikembangkan tanaman mendong di wilayah tertentu, namun dilakukan pada lahan-lahan yang ditentukan secara selektif. Pelatihan atau bimbingan pengrajin agar secara terus menerus menciptakan inovasi baru dalam desain produk sehingga lebih variatif. Penataan kelembagaan, penataan antara pengrajin dan pemilik modal agar memiliki keseimbangan dalam tanggung jawab dan resiko, mencari peluang pasar ekspor yang baru, disamping mempertahankan pasar yang selama ini berjalan. Memberikan insentif kepada pengrajin agar 
tidak meninggalkan pekerjaan kerajinannya pada saat menggarap lahan pertanian dan memberikan pengetahuan ke sekolah-sekolah tentang kerajinan dan pembuatan mendong.

Upaya memberikan pengetahuan ke sekolah-sekolah tentang kerajinan dan pembuatan mendong inilah yang menjadi inspirasi penulis untuk membuat tugas akhir tentang perancangan animasi berbasis multimedia interaktif sebagai media pembelajaran kerajinan mendong bagi siswa-siswi setingkat SMP dan SMA. Perancangan animasi yang akan dikembangkan menggunakan piranti lunak Adobe Flash.

Hofstetter [1] memaknai multimedia adalah suatu penggunaan komputer untuk menampilkan dan mengkombinasikan teks, grafik, suara / audio, dan video dengan links dan tools sehingga pengguna dapat bernavigasi, berinteraksi, membuat, dan berkomunikasi dengan komputer. Ada empat komponen dalam sistem multimedia, yaitu:

a. Perangkat Komputer.

b. Adanya keterhubungan antara informasi yang satu dengan informasi yang lainnya.

c. Adanya alat navigasi yang membuat kita dapat berinteraksi dengan aplikasi yang ada di dalamnya.

d. Adanya fasilitas untuk mengumpulkan dan memproses informasi

Kelebihan dari multimedia adalah menarik indra dan menarik minat, karena merupakan gabungan antara pandangan, suara, dan gerakkan. Lembaga riset dan penerbitan komputer yaitu Computer Teknology Research (CRT) menyatakan bahwa orang hanya mampu mengingat $20 \%$ dari yang dilihat dan 30\% dari yang didengar . tetapi orang mengingat 50\% dari yang dilihat dan yang didengar dan $80 \%$ dari yang dilihat, didengar, dan yang dilakukan secara langsung[2].

Pentingnya penggunaan multimedia menurut Suyanto [3] antara lain:

a. Membantu meratakan zaman informasi ke jutaan orang yang belum memakai komputer.

b. Menyampaikan informasi secara efektif, karena tidak hanya menampilkan teks semata tetapi juga menghidupkan teks dengan menyertakan bunyi, gambar, musik, animasi, dan video.

c. Mendorong keterlibatan dan penggalian lebih jauh atas aplikasi multimedia untuk pengajaran dan pendidikan dalam rangka meraih keunggulan bersaing perusahaan.

Shneiderman [4] memberikan pedoman yang sering dipakai oleh para perancang dalam merancang antarmuka pemakai, yaitu delapan aturan emas perancangan dialog (The Eight Golden Rules of Dialog Design), antara lain:

a. Berusaha keras untuk konsisten

Adanya kesamaan istilah dan ungkapan yang digunakan secara global dalam sebuah sistem. Hal yang sama juga berlaku untuk warna, tipe, dan cara penulisan.

b. Adanya shortcut untuk pemakai berpengalaman

Adanya tombol-tombol dan perintah-perintah khusus yang dapat digunakan oleh pemakai berpengalaman untuk mendapatkan waktu respon dan penampilan informasi ke layar yang lebih cepat.

c. Adanya umpan balik yang informatif

Untuk setiap tindakan pemakai, maka sistem akan merespon dengan umpan balik yang sesuai.

d. Rancang dialog untuk memberikan keadaan akhir

Yang dimaksudkan adalah menghindari penyelesaian otomatis dan memungkinkan pemakai memberi tanda bahwa pekerjaan telah selesai atau konfirmasi.

e. Adanya pencegahan dan penanganan kesalahan yang sederhana

Sedapat mungkin rancang sebuah sistem sehingga pemakai tidak dapat melakukan kesalahan yang serius. Dan untuk setiap kesalahan kecil dari pihak pemakai, sistem dapat memperbaiki sendiri kesalahan tersebut.

f. Sedapat mungkin tindakan yang diambil dapat dibatalkan

Seluruh tindakan yang mempengaruhi sistem secara keseluruhan dapat dibatalkan atau undo

g. Berikan kendali kepada pemakai

Letakkan pemakai di posisi pelaku tindakan dan bukan sekedar menanggapi tindakan dari sistem.

h. Kurangi beban informasi yang berlebihan 
Mayer [5] mendefinisikan multimedia sebagai presentasi materi dengan menggunakan kata-kata sekaligus gambar-gambar. Yang dimaksud dengan kata disini adalah materinya disajikan dengan verbal form atau bentuk verbal. Sedangkan Phillips [6] menyatakan multimedia adalah gabungan dari teks, gambar, suara, animasi dan video, beberapa komponen tersebut atau seluruh komponen tersebut dimasukan ke dalam program yang koheren.

Multimedia memungkinkan pemakai komputer untuk mendapatkan output dalam bentuk yang lebih kaya dari pada media konvensional. Multimedia melibatkan perangkat keras dan perangkat lunak. Istilah multimedia identik dengan komputer multimedia, yaitu komputer yang memiliki kemampuan olah data, olah kata, olah gambar, dan olah gerak di mana masingmasing unsur tersebut saling melengkapi, menunjang, dan saling membantu.

Pembelajaran dapat diartikan sebagai proses penciptaan lingkungan yang memungkinkan terjadinya proses belajar. Belajar dalam pengertian aktifitas mental pengguna dalam berinteraksi dengan lingkungan sehingga menghasilkan perubahan perilaku yang bersifat relative berkelanjutan. Dengan demikian multimedia pembelajaran merupakan aplikasi multimedia yang digunakan dalam proses pembelajaran dalam menyalurkan pesan (pengetahuan, keterampilan dan sikap) serta dapat merangsang pikiran, perasaan, perhatian dan kemauan belajar sehingga proses belajar terjadi, bertujuan dan terkendali.

Gafur [7] menyebutkan beberapa prinsip yang harus diperhatikan dalam pengembangan media pembelajaran yaitu meliputi prinsip kesiapan dan motivasi, penggunaan alat pemusat perhatian, pengulangan, partisipasi aktif pengguna, dan umpan balik.

Prinsip kesiapan dan motivasi menekankan bahwa kesiapan dan motivasi pengguna untuk menerima informasi pembelajaran sangat berpengaruh terhadap keberhasilan proses pembelajaran. Kesiapan pengguna mencakup kesiapan pengetahuan prasyarat, kesiapan mental, dan kesiapan fisik. Motivasi merupakan dorongan untuk melakukan atau mengikuti kegiatan belajar. Motivasi tersebut dapat berasal dari dalam diri maupun dari luar diri peserta didik.

Penggunaan alat pemusat perhatian dalam media pembelajaran dapat menjadi daya tarik tersendiri bagi pengguna untuk fokus terhadap materi pelajaran. Hal ini membantu konsentrasi pengguna dalam memahami isi pelajaran sehingga penguasaan mereka menjadi lebih baik.

Informasi atau keterampilan baru jarang sekali dapat dikuasai secara maksimal hanya dengan satu kali proses belajar. Agar penguasaan terhadap informasi atau keterampilan baru tersebut dapat lebih optimal, maka perlu dilakukan beberapa kali pengulangan. Prinsip pengulangan ini harus diperhatikan dalam mengembangkan media pembelajaran.

Proses pembelajaran akan lebih berhasil manakala terjadi interaksi dua arah antara media pembelajaran dan pengguna. Partisipasi aktif pengguna dalam proses pembelajaran dapat meningkatkan pemahaman dan penguasaan materi pelajaran. Oleh karena itu media pembelajaran yang digunakan hendaknya mampu menimbulkan keterlibatan pengguna secara aktif (interaktif) dalam proses belajar.

Umpan balik yang diberikan oleh media pembelajaran secara tepat dapat menjadi pendorong bagi pengguna untuk selalu meningkatkan pemahamannya. Untuk itu media pembelajaran harus memberikan respon umpan balik secara berkala terhadap kemajuan belajar pengguna.

\section{METODE PENELITIAN}

Metode pengumpulan data dalam perancangan animasi sebagai media pembelajaran ini dilakukan sebagai penelitian awal, penulis menggunakan beberapa metode sebagai berikut:

a. Metode Observasi / Observation

Penulis melakukan pengamatan secara langsung terhadap kegiatan di pusat kerajinan Mendong.

b. Metode Wawancara/ Interview

Penulis mengumpulkan informasi dan data dengan cara mengadakan wawancara secara langsung dengan para pihak terkait. 
c. Metode Kearsipan/ Documentation

Penulis melakukan pengumpulan data dengan cara membaca dan mempelajari data dan arsip yang sudah ada serta pengambilan foto-foto kegiatan dan produk yang terkait dengan pembuatan kerajinan mendong.

d. Metode Kepustakaan/ Library

Penulis melakukan pengumpulan data dengan cara membaca dan mempelajari dari bukubuku pustaka yang telah ada untuk digunakan sebagai referensi atau digunakan sebagai bahan pembanding.

Struktur informasi multimedia merupakan bagian yang sangat penting dari keseluruhan pembuatan aplikasi multimedia. Struktur ini berguna untuk memvisualisasikan seluruh relasional dari aplikasi yang sedang dibangun. Struktur ini menjelaskan organisasi file dari Adobe sebagai software utama, grafik dan sumber daya lain, sehingga tidak hanya memudahkan dalam menemukan file tertentu, tetapi memudahkan untuk melakukan revisi pada tiap-tiap komponen dalam aplikasi multimedia ketika dibutuhkan.

Didalam multimedia ada empat struktur yang dimaksudkan, masing-masing struktur memiliki tujuan dan kegunaan yang berbeda-beda. Struktur sistem infomasi multimedia [8]: bersamaan.

Struktur hierarki lebih cocok digunakan untuk menunjukan semua level secara

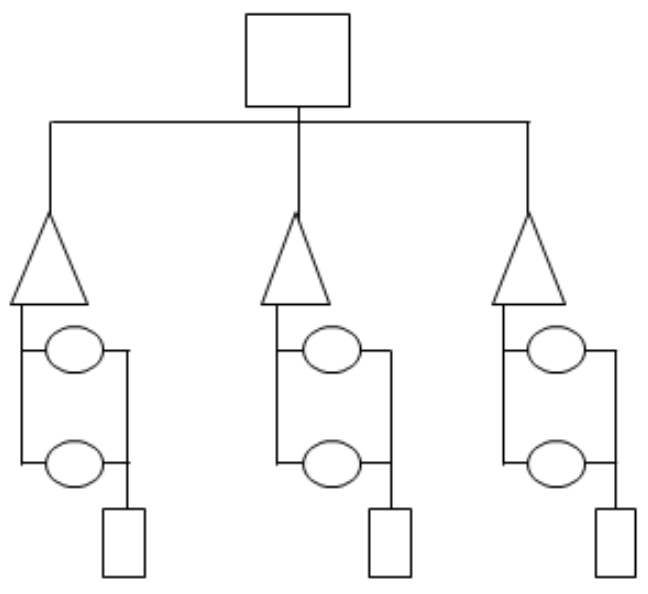

Gambar 1 Struktur Hierarki

Keterangan:

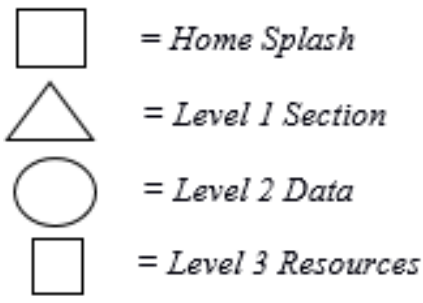

Berikut adalah gambar pengembangan Proses pengembangan sistem multimedia dengan tahapan-tahapannya sebagai berikut. [9] 


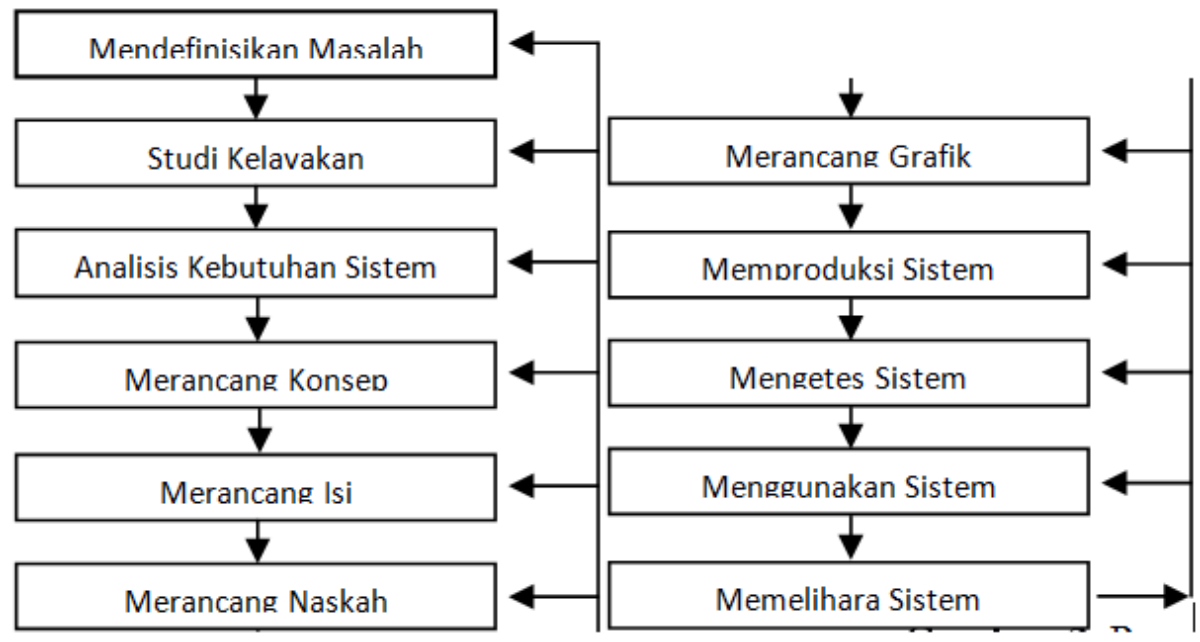

Gambar 2. Proses Pengembangan Sistem Multimedia

1. Mendefinisikan masalah. Analis sisitem mendefinisi kebutuhan pemakai dan menentukan bahwa pemecahannya memerlukan multimedia.

2. Studi Kelayakan adalah studi yang digunakan untuk menentukan kemungkinan apakah pengembangan proyek sistem multimedia layak diteruskan atau dihentikan.

3. Analisis kebutuhan sistem ini sangat diperlukan sekali dalam mendukung kinerja sistem, apakah sistem yang penulis buat sesuai dengan kebutuhan yang diperlukan oleh sebuah instansi ataupun perusahan. Karena kebutuhan sistem ini akan mendukung tercapainya tujuan suatu instansi ataupun perusahaan.

4. Merancang konsep. Analis sistem dan pemakai mungkin bekerja sama dengan profesional komunikasi seperti produser, sutradara, dan teknisi video, terlibat dalam rancangan konsep yang menentukan keseluruhan pesan dan memeriksa suatu urutan utama.

5. Merancang isi. Pengembangan terlibat dalam rancangan isi dengan menyiapkan spesifikasi aplikasi yang rinci.

6. Menulis naskah. Dialog dan semua elemen terinci dari urutan ditentukan.

7. Merancang grafik. Grafik dipilih yang mendukung dialog, latar belakang atau perlengkapan yang perlu digunakan dalam video.

8. Memproduksi sistem. Pengembang sistem memproduksi bagian sistem dan menyatukannya dengan sistem. Selain sebagai pengembang perangkat lunak aplikasi, tugasnya mencakup kegiatan khusus seperti menyunting video dan authoring. Authoring adalah pengintegrasian elemen-elemen yang terpisah dengan menggunakan perangkat lunak siap pakai khusus.

9. Melakukan tes pemakai. Analis sistem membidik pemakai dalam menggunakan sistem dan memberi kesempatan pada pemakai untuk akrab dengan semua feature.

10. Menggunakan sistem. Pemakai memanfaatkan sistem.

11. Memelihara sistem. Seperti sistem berbasis komputer lain, sistem multimedia harus dipelihara. Perbedaan utamanya adalah pemakai tidak diharapkan untuk melaksanakan pemeliharaan, ini adalah tugas para spesialis dan profesional.

Penelitian ini menggunakan teknik analisis statistik deskriptif. Teknik analisa data ini digunakan untuk mengolah data yang diperoleh melalui angket dalam bentuk skor yang diubah menjadi nilai. [10] 
Tabel 1. Konversi Skor Menjadi Nilai pada Skala Lima

\begin{tabular}{|c|c|c|}
\hline \multicolumn{2}{|c|}{ Interval Skor } & Nilai \\
\hline$X>X i+1,80 S b i$ & $X>4,21$ & Sangat Layak \\
\hline$X i+0,60 S b i<X \leq X i+1,80 S b i$ & $3,40<X \leq 4,21$ & Layak \\
\hline$X i-0,60 S b i<X \leq X i+1,80 S b i$ & $2,60<X \leq 3,40$ & Cukup Layak \\
\hline$X i-1,80 S b i<X \leq X i-1,80 S b i$ & $1,79<X \leq 2,60$ & Tidak Layak \\
\hline$X \leq X i-1,80 S b i$ & $X \leq 1,79$ & Sangat Tidak Layak \\
\hline
\end{tabular}

Keterangan:

- Rerata Ideal $(X i)=1 / 2 \times$ (skor maksimal + skor minimal).

- Simpang Baku Skor Ideal $(S b i)=1 / 6$ x (skor maksimal - skor minimal).

- Skor Maksimal = 5

- Skor Minimal $=1$

$-X i=1 / 2 x(5+1)=3$

$-\mathrm{Sbi}=1 / 6 \times(5-1)=0,67$

\section{HASIL DAN PEMBAHASAN}

Pembuatan aplikasi yang interaktif tersebut disesuaikan dengan pemakai atau user yaitu usia generasi setingkat SMP/SMA yang ingin mengetahui dan mempelajari tentang teknik pembuatan kerajinan mendong. Agar aplikasi tersebut interaktif, penulis mencoba membuat tombol navigasi yang berfungsi untuk melihat informasi yang ada, selain itu animasi yang menarik sebagai ilustrasi dari informasi yang akan disampaikan.

Dalam pembuatan aplikasi multimedia ini, penulis menggunakan unsur-unsur multimedia seperti teks, suara, gambar dan video. Untuk memberi kesan hidup pada aplikasi ini penulis menambahkan animasi pada gambar atau foto dan teks.

Dalam penyusunan tampilan pembuatan aplikasi Interaktif berdasarkan pada dimulainya informasi mengenai kerajinan mendong, yaitu:

1. Sejarah

2. Cara pembuatan

3. Galeri

4. Lokasi kerajinan

Karena sifat aplikasi yang interaktif maka untuk pemilihan input pemakai menggunakan mouse dan untuk output visual dapat dilihat pada layar monitor. Sedang output suara dapat didengar dengan menggunakan speaker.

Guna mempermudah dalam menyusun ide-ide, penulis menggunakan sebuah struktur. Struktur yang dipakai adalah desain hierarki. Penulis memakai bentuk desain tersebut karena pemakai (user) dapat dengan mudah memilih data yang senada tanpa harus kembali ke menu utama. Struktur ini memungkinkan untuk menampilkan isi halaman tanpa melalui transisi yang menyita waktu. 
Citec Journal, Vol. 1, No. 3, Mei 2014 - Juli 2014

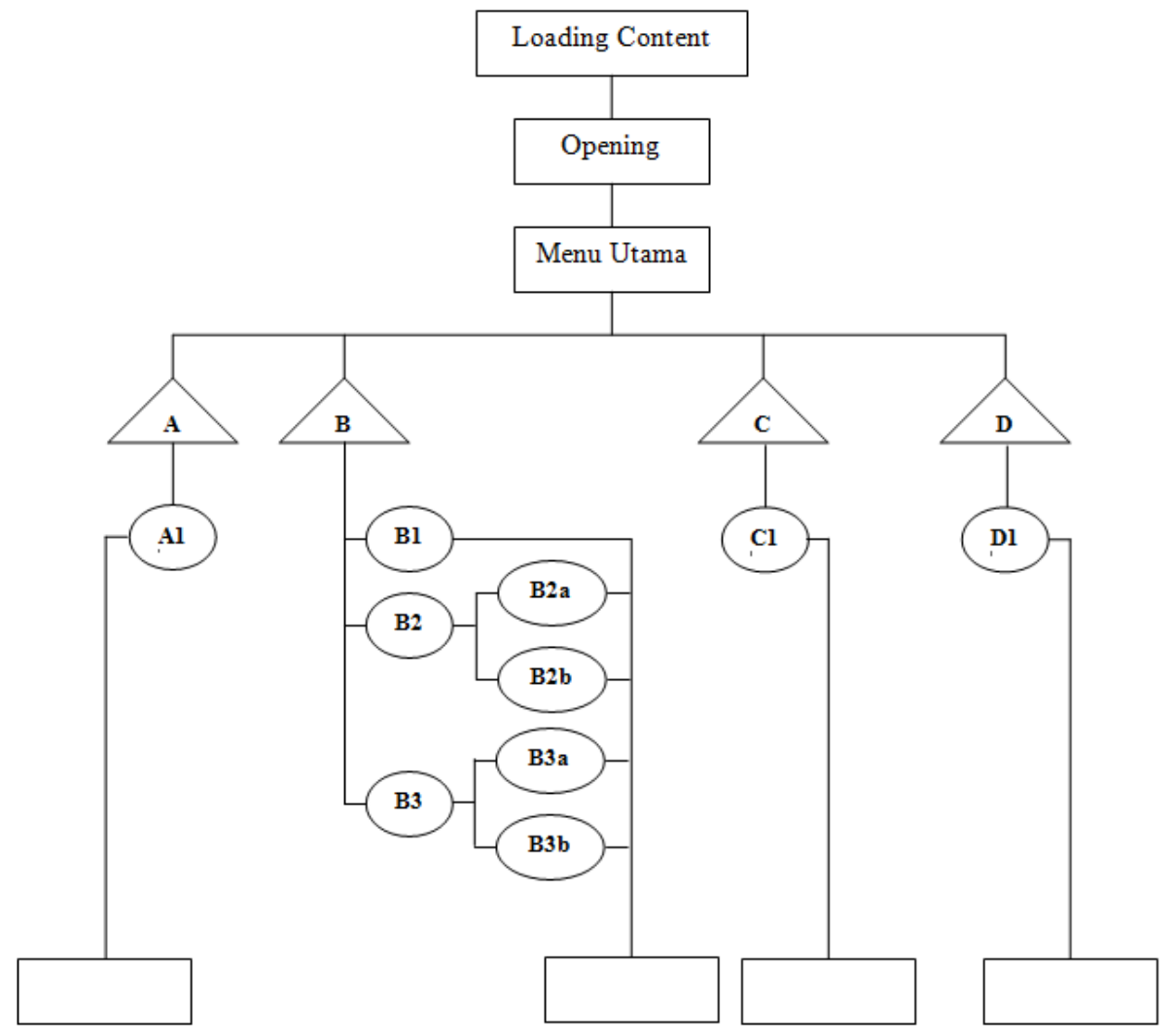

Gambar 3. Struktur Desain Hierarki

Keterangan:

A : Sejarah

A.1 : Sejarah Kerajinan Mendong

B : Cara Pembuatan

B.1 : Cara Pembuatan Kerajinan

B.2 : Anyaman Tunggal

B.2.a : Tunggal Dasar

B.2.b : Tunggal Variasi

B.3 : Anyaman Ganda

B.3.a : Ganda Dasar

B.3.b : Ganda Variasi

C : Galeri

C.1 : Hasil Karya Kerajinan Mendong

D : Lokasi Kerajinan

D.1 : Lokasi Usaha dan Alamat Usaha 


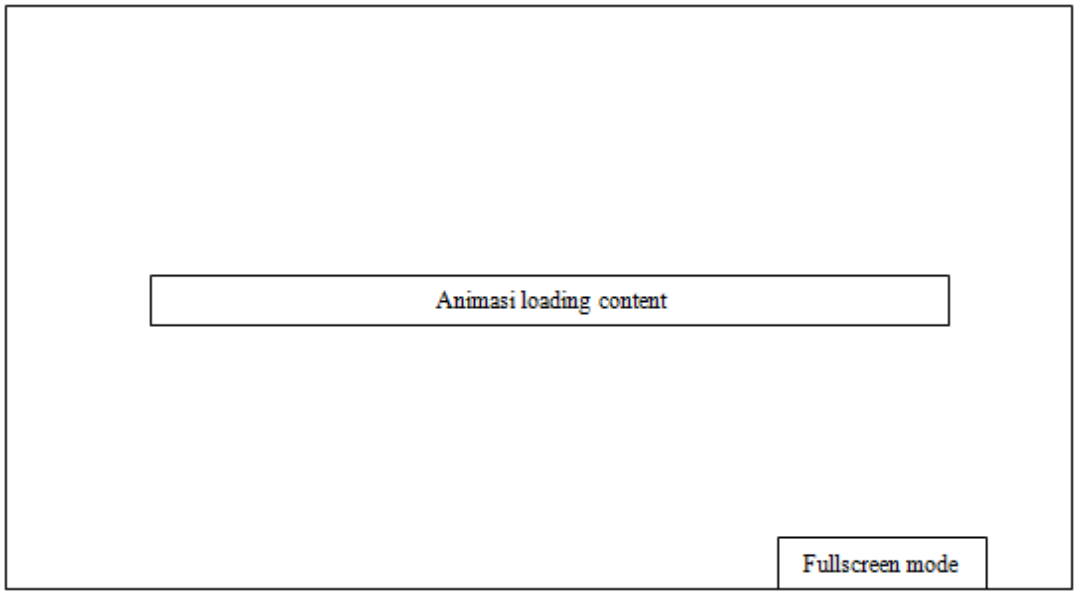

Gambar 4. Loading Content

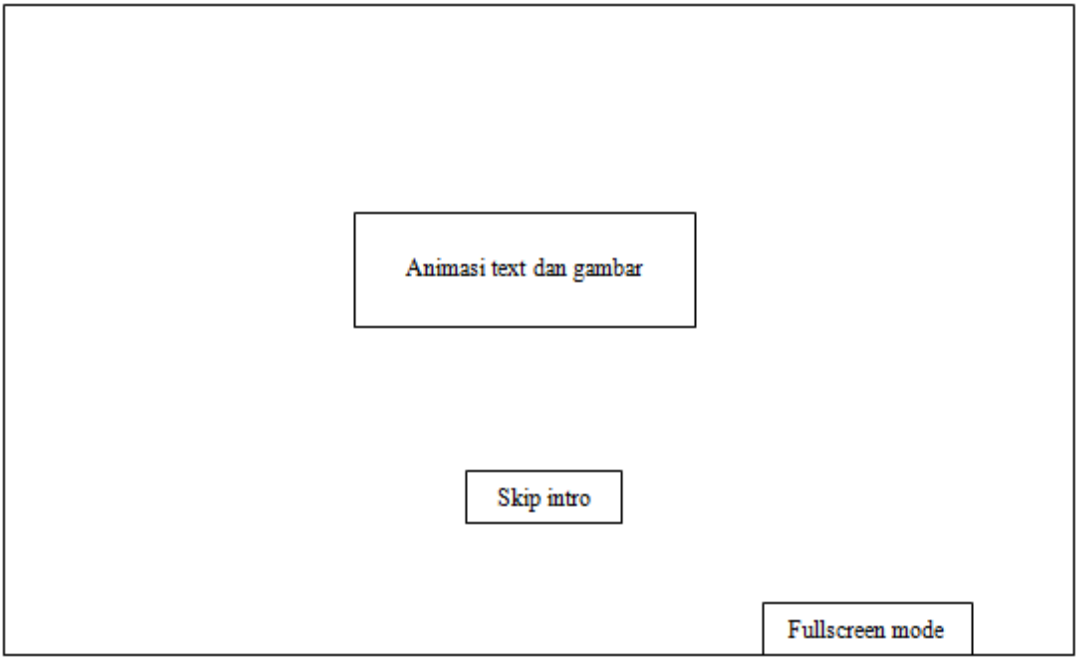

Gambar 5. Rancangan Halaman Intro

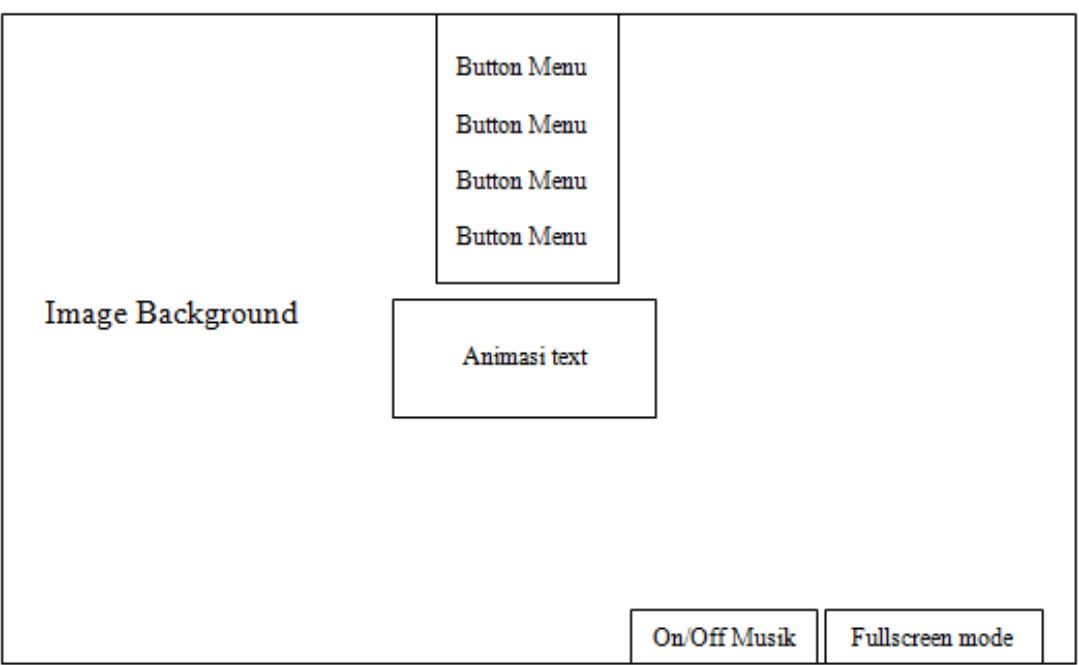

Gambar 6. Rancangan Halaman Menu Utama 
Citec Journal, Vol. 1, No. 3, Mei 2014 - Juli 2014

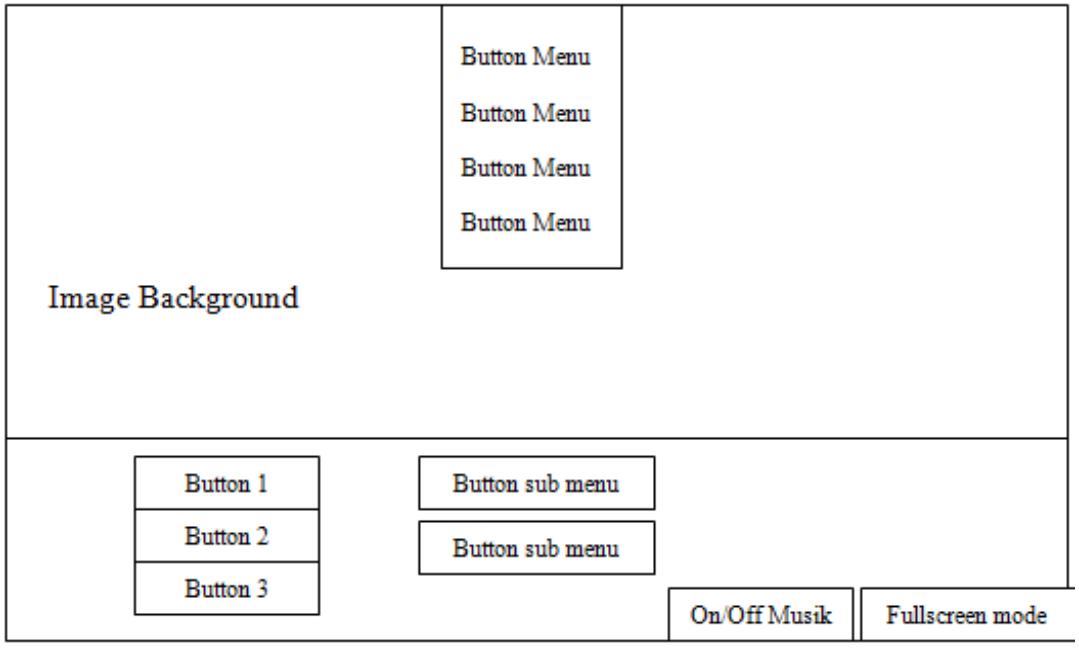

Gambar 7. Rancangan Halaman Sub Menu

Setelah merancang, maka selanjutnya mengimplementasikan apa yang telah dirancang sebelumnya. Implementasi program perancangan animasi sebagai media pembelajaran kerajinan mendung dengan teknik anyam berbasis multimedia interaktif sebagai media pembelajaran untuk membantu visualisasi dalam pembuatan kerajinan mendong merupakan tahap paling penting dimana sistem yang sudah dirancang, diimplementasikan untuk menghasilkan aplikasi yang sesuai dan siap dioperasikan pada keadaan yang sebenarnya. Dari sini diketahui apakah sistem yang dibuat benar-benar dapat dihasilkan sesuai dengan tujuan yang diinginkan.

Tahap demi tahap perancangan suatu aplikasi telah dikerjakan. Dimulai dari rancangan sistem, rancangan storyboard, rancangan naskah, rancangan grafik, rancangan audio, rancangan video, dan rancangan animasi. Semua rancangan ini berguna untuk mempermudah dalam penjabaran sistem ke dalam multimedia interaktif.

Loading content ini merupakan animasi sederhana dan pemanggilan content-content yang akan dijalankan di aplikasi, menu tersebut ditujukan pada gambar 8 .

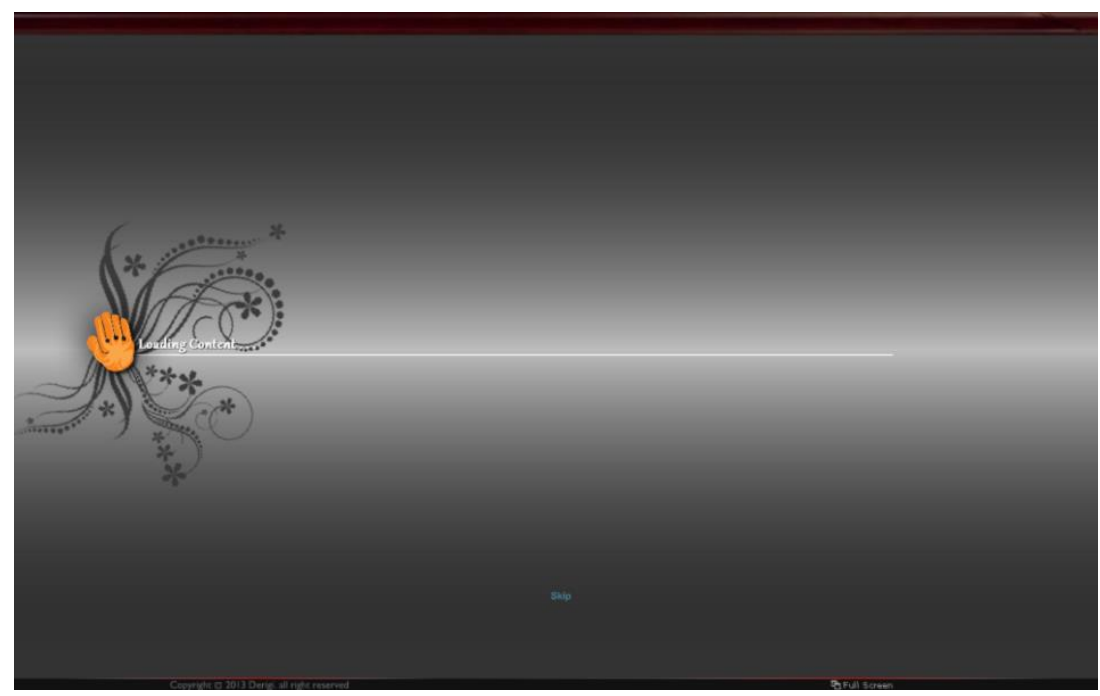

Gambar 8. Tampilan Loading Content

Tampilan awal aplikasi ini ini hanya terdapat sedikit menu yaitu (1) Sejarah, (2) Cara Pembuatan, (3) Galeri, dan (4) Lokasi Kerajinan. Menu tersebut ditunjukan pada gambar 9. 


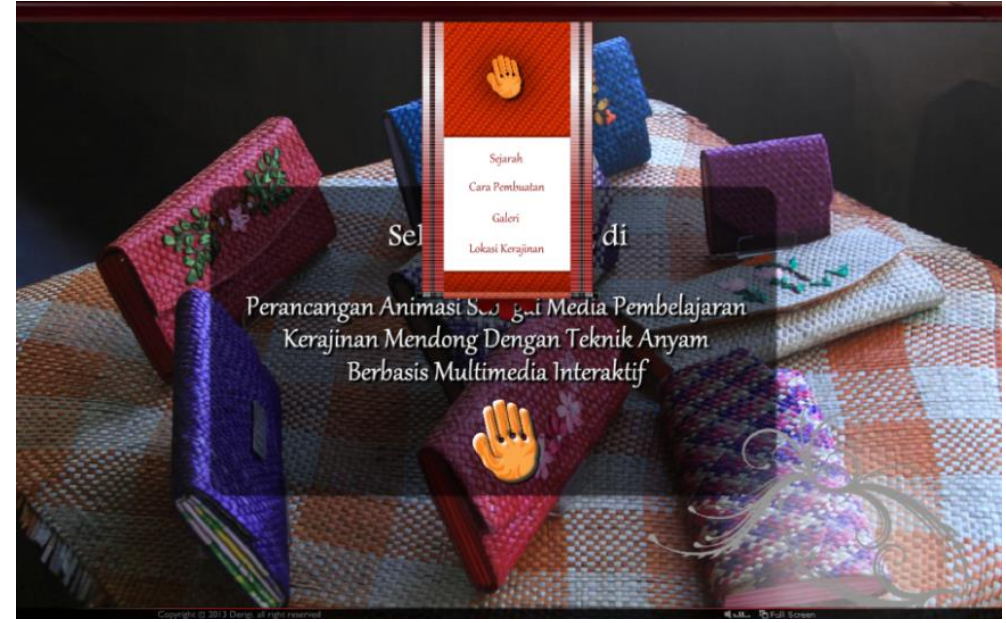

Gambar 9. Tampilan Menu Utama

Di menu Cara Pembuatan ini terdapat sub menucara pembuatan yaitu : (1) Cara Pembuatan, (2) Anyaman Tunggal yang terdapat dua sub menu yaitu menu Tunggal Dasar dan Tunggal Variasi, dan (3) Anyaman Ganda yang terdapat dua sub menu yaitu Ganda Dasar dan Ganda Variasi, Menu tersebut ditunjukan pada gambar 10.

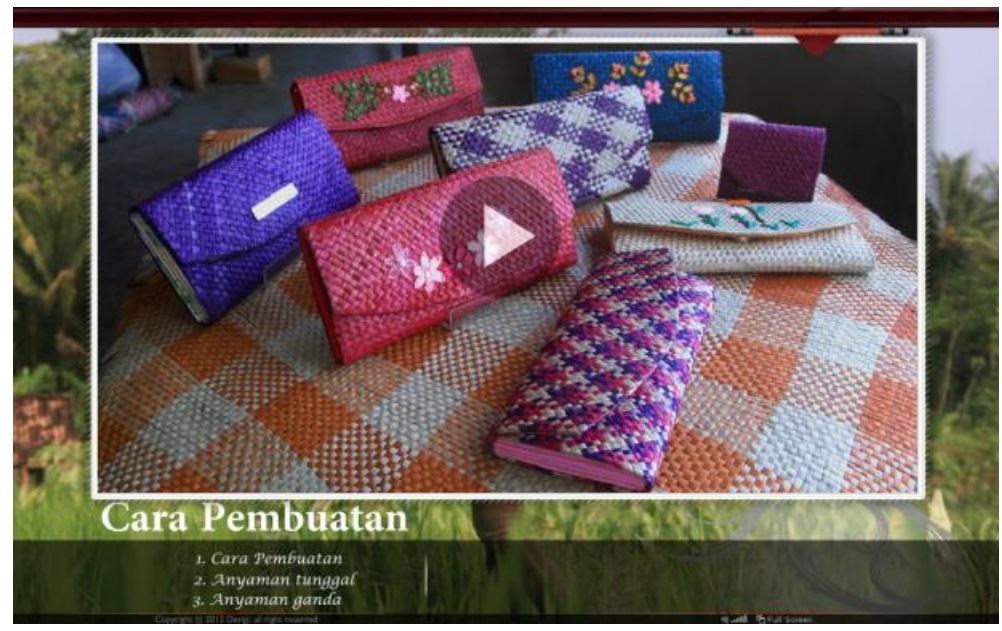

Gambar 10 Tampilan Sub Menu Pembuatan

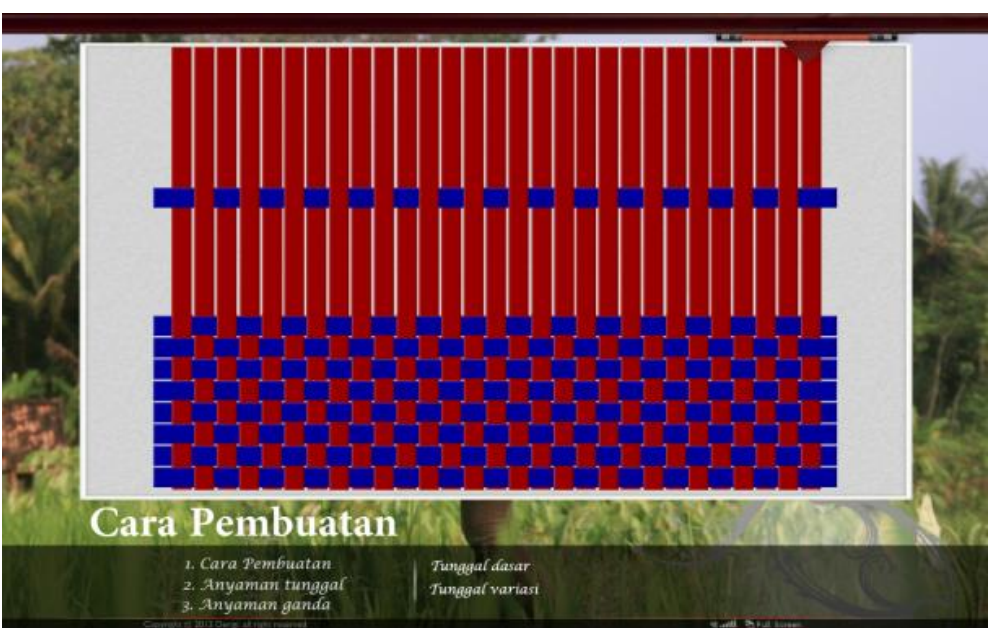

Gambar 11 Tampilan Sub menu Tunggal Dasar 
Citec Journal, Vol. 1, No. 3, Mei 2014 - Juli 2014

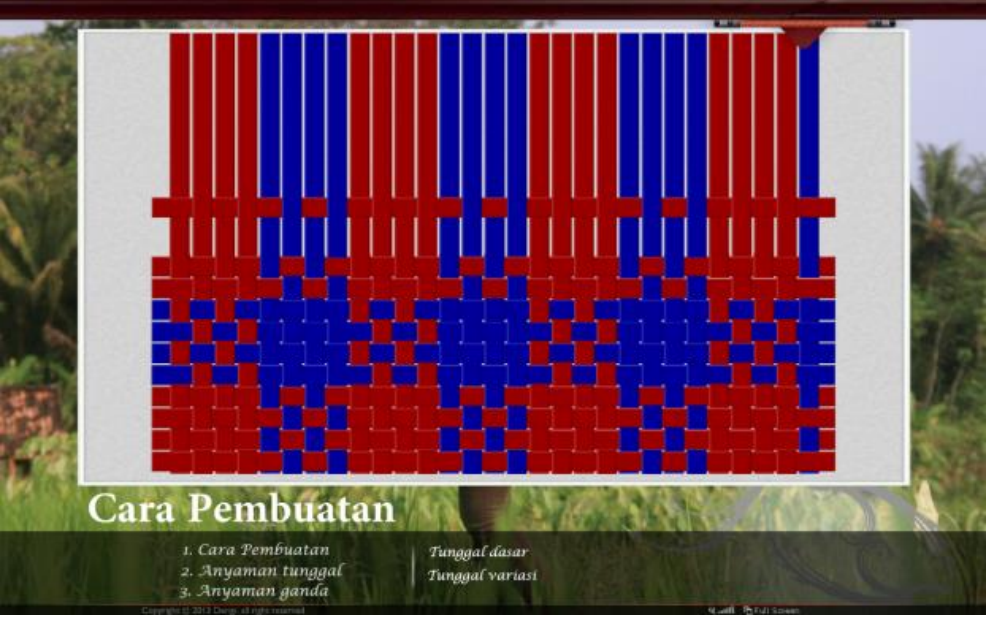

Gambar 12. Tampilan Sub Menu Tunggal Variasi

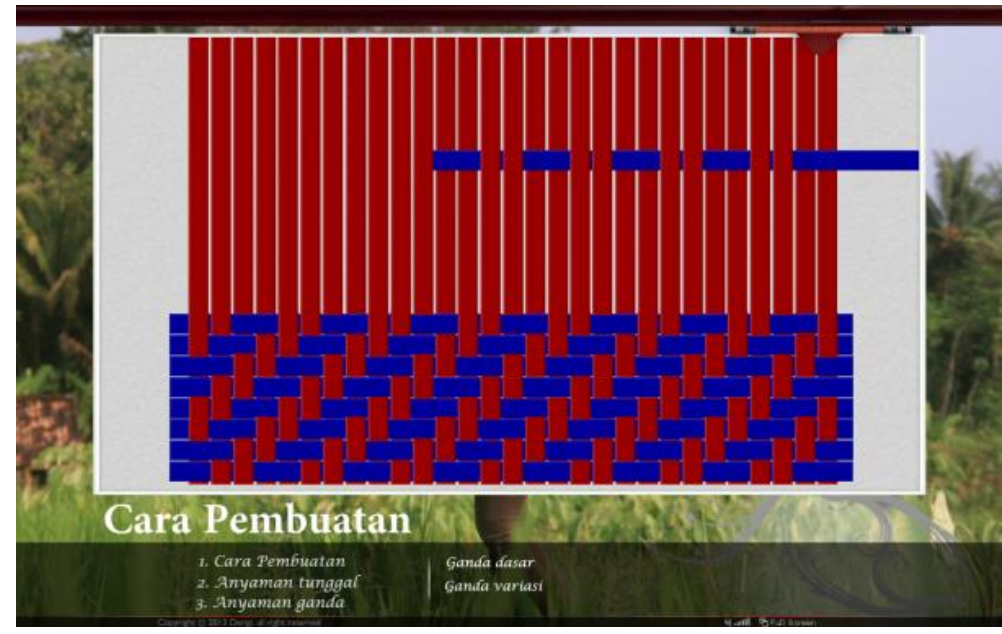

Gambar 13. Tampilan Sub Menu Ganda Dasar

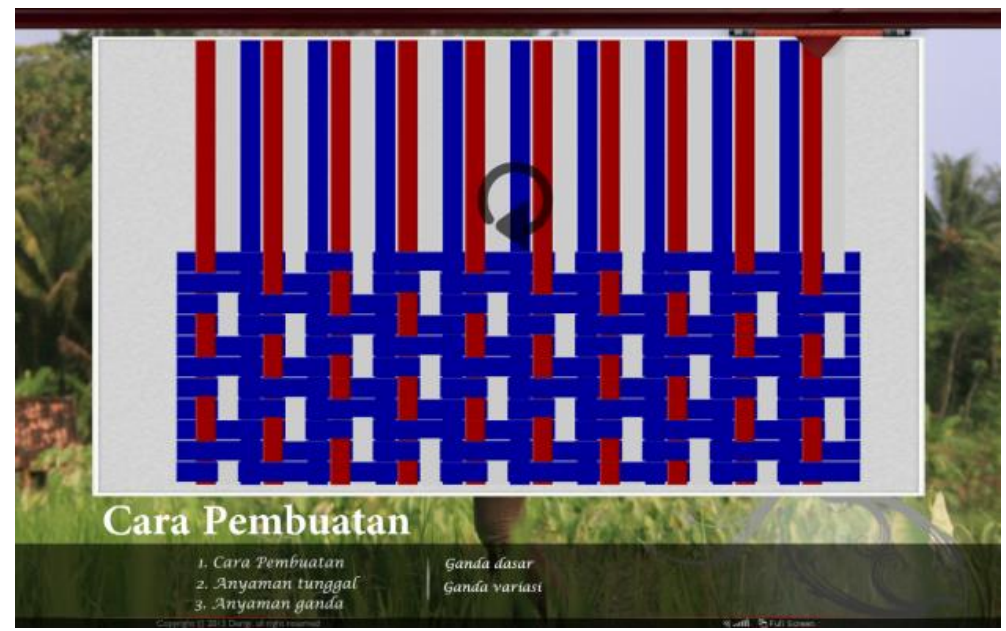

Gambar 14. Tampilan Sub Menu Tunggal Variasi

Ujicoba sistem merupakan langkah setelah aplikasi multimedia diproduksi. Fungsi dari ujicoba adalah memastikan bahwa hasil produksi aplikasi multimedia sesuai dengan yang direncanakan. Test data harus disiapkan secara hati-hati. Kajian hasil test dan koreksi yang dibuat didalam (sistem) aplikasi multimedia. Pengetesan pada perkembangan sistem multimedia 
dapat dipecahkan dalam tiga aktifitas yaitu unit sistem dan pengetesan. Unit pengetesan terdiri dari pengetesan masing-masing program secara terpisah dalam sistem multimedia. Fungsi dari masing-masing pengetesan adalah sebagai garansi bahwa program tersebut bebas dari kesalahan. Sistem pengetesan adalah berfungsinya sistem multimedia secara keseluruhan. Sistem tersebut mencoba menentukan apakah cara kerja sistem yang dibangun sesuai atau tidak. Jaminan kualitas menjadikan sertifikasi akhir yang menunjukan bahwa sistem sesuai dengan standard kualitas yang diharapkan dan sistem sudah dapat digunakan. Telah dilakukan uji coba oleh penyusun pada komputer dengan spesifikasi sebagai berikut :
a. Sistem Operasi Windows XP Professional.
b. Prosessor Intel (R) Pentium (R) CPU 2,26 GHz.
c. Motherboard Intel 81845PE-RZ(-C).
d. VGA NVIDIA GeForce4 MX 440.
e. Sound Card Realtek RTL8139/810x Family Fast Ethernet NIC.
f. RAM $256 \mathrm{Mb}$.
g. HD 40GB.
h. Combo 52x speed DVD ROM, CD RW.
i. Monitor 17".
j. Speaker Aktif Simbada CST 5000.

Pengujian awal yang dilakukan adalah black box testing. Pengujian ini berusaha menemukan kesalahan yang terdapat pada aplikasi dengan kategori: (1) fungsi-fungsi yang tidak benar atau hilang, (2) kesalahan interface, (3) kesalahan dalam struktur data atau akses data, (4) kesalahan kinerja, dan (5) inisialisasi dan kesalahan terminasi. Hasil pengujian menunjukan bahwa untuk kerja aplikasi pada fungsi navigasi dan tombol 100\%berjalan baik.

Validasi ahli materi dilakukan oleh dua orang ahli materi. Aspek yang dinilai adalah desain interaktif, konten materi, kualitas informasi.

Tabel 2. Pengolahan Hasil Validasi Ahli Materi

\begin{tabular}{|l|l|l|l|l|}
\hline No. & Aspek Penilaian & $\boldsymbol{\Sigma}$ Nilai & $\begin{array}{l}\text { Rata-rata } \\
\boldsymbol{\Sigma} \text { Nilai }\end{array}$ & Kategori \\
\hline 1 & Desain interaktif & 51 & 4.25 & $\begin{array}{l}\text { Sangat } \\
\text { layak }\end{array}$ \\
\hline 2 & Konten Materi & 83 & 4.15 & Layak \\
\hline 3 & Kualitas alat evaluasi & 54 & 4.27 & $\begin{array}{l}\text { Sangat } \\
\text { Layak }\end{array}$ \\
\hline \multicolumn{2}{|l|}{ Total } & $\mathbf{1 8 8}$ & $\mathbf{4 . 2 7}$ & $\begin{array}{l}\text { Sangat } \\
\text { Layak }\end{array}$ \\
\hline
\end{tabular}

Validasi ahli media dilakukan oleh tiga orang ahli media. Aspek yang dinilai adalah tampilan aplikasi, pengoperasian aplikasi, dan Interaksi.

Tabel 3. Tabel Pengolahan Hasil Validasi Ahli Media

\begin{tabular}{|l|l|l|l|l|}
\hline No. & Aspek Penilaian & $\boldsymbol{\Sigma}$ Nilai & $\begin{array}{l}\text { Rata-rata } \\
\boldsymbol{\Sigma} \text { Nilai }\end{array}$ & Kategori \\
\hline 1 & Tampilan Aplikasi & 183 & 4.36 & $\begin{array}{l}\text { Sangat } \\
\text { layak }\end{array}$ \\
\hline 2 & Pengoprasian Aplikasi & 77 & 4.28 & $\begin{array}{l}\text { Sangat } \\
\text { layak }\end{array}$ \\
\hline 3 & Interaksi & 66 & 4.4 & $\begin{array}{l}\text { Sangat } \\
\text { Layak }\end{array}$ \\
\hline \multicolumn{2}{|l|}{ Total } & $\mathbf{3 2 6}$ & $\mathbf{4 . 3 5}$ & $\begin{array}{l}\text { Sangat } \\
\text { Layak }\end{array}$ \\
\hline
\end{tabular}


Setelah aplikasi pembelajaran yang dikembangkan divalidasi oleh ahli maka langkah selanjutnya adalah uji coba aplikasi pembelajaran terhadap pengguna. Adapun aspek yang dinilai adalah aspek kemanfaatan, tampilan aplikasi, dan kemudahan. Dari angket yang telah dibagikan, didapatkan data yang disajikan pada tabel berikut:

Tabel 4. Hasil Pengolahan Angket Penilaian Pengguna

\begin{tabular}{|l|l|l|l|l|}
\hline No. & Aspek Penilaian & $\boldsymbol{\Sigma}$ Nilai & $\begin{array}{l}\text { Rata-rata } \\
\boldsymbol{\Sigma} \text { Nilai }\end{array}$ & Kategori \\
\hline 1 & Kemanfaatan & 373 & 4.14 & Layak \\
\hline 2 & Tampilan Aplikasi & 1267 & 4.22 & $\begin{array}{l}\text { Sangat } \\
\text { layak }\end{array}$ \\
\hline 3 & Kemudahan & 868 & 4.13 & Layak \\
\hline \multicolumn{2}{|l|}{ Total } & $\mathbf{3 2 6}$ & $\mathbf{4 . 1 8}$ & Layak \\
\hline
\end{tabular}

\section{KESIMPULAN}

Dari penjelasan dan penguraian pada pembahasan sebelumnya dan sampai akhir dari perancangan aplikasi. Maka dapat disimpulkan bahwa aplikasi informasi dengan menggunakan multimedia:

1. Animasi penganyaman masih menggunakan metode dasar yang bisa dipelajari dengan melihat visualisasi $2 \mathrm{D}$.

2. Aplikasi multimedia ini memuat informasi proses kerajinan mending sesuai kebutuhan dan fakata yang sebenarnya.

3. Teknologi informasi seperti aplikasi multimedia ini dapat menjadi media alternative dalam sebuah media edukatif yang menarik dan untuk langkah lebih lanjut dapat dijadikan contoh dalam pengembangananya di bidang serupa atau bidang lainnya.

4. Pembangunan aplikasi ini cukup menggunakan action script 2.0 dan dapat digunakan pada semua software flash versi apapun.

\section{SARAN}

Untuk lebih memahami tentang sebuah sistem informasi multimedia diperlukan pemahaman program aplikasi serta special efek yang baik, untuk itu, penulis memberikan saran dan masukan yang dapat dipertimbangkan, sebagai berikut:

1. Pertimbangan teknologi multimedia akan terus berlanjut seiring banyaknya media komunikasi yang ada, sehingga membutuhkan perhatian dan perencanaan jangka panjang yang matang untuk mengatisipasinya.

2. Aplikasi ini tidak menggunakan database untuk menyimpan data, untuk pengembangan selanjutnya perlu dirancang database agar data lebih bersifat dinamis.

3. Pembahasan aplikasi multimedia ini masih dimungkinkan untuk melibatkan animasianimasi maupun video untuk memperjelas informasi.

4. Perbanyak sumber daya manusia yang memiliki kualitas yang baik, dalam hal ini sebagai pengolah aplikasi multimedia.

5. Masukan penulis, semoga para pengolah aplikasi multimedia berikutnya dapat menambahkan fitur-fitur yang masih kurang guna peneyempurnaan, seperti penggunaan dua bahasa, keamanan, dan lainya.

Aplikasi yang penyusun buat belum sempurna, untuk itu diharapkan nantinya dapat diberikan tambahan fitur - fitur yang lebih baik sehingga dapat lebih bermanfaat lagi. 


\section{DAFTAR PUSTAKA}

[1] Hofstetter, F. T., 2001, Multimedia Literacy, Mc Graw-Hill International Edition, New York.

[2] Munir, 2012, Multimedia Konsep Dan Aplikasi Dalam Pendidikan, Alfabeta, Bandung.

[3] Suyanto, M., 2003, Multimedia Alat Untuk Meningkatkan Keunggulan Bersaing, Andi Offset, Yogyakarta.

[4] Shneiderman, B., 2005, Designing the User Interface: Strategies for Effective Human Computer Interaction, Addison Wesley Longman Inc, USA.

[5] Mayer, R. E., 2009, Multimedia Learning, Cambridge University Press, London.

[6] Philips, R., 1997, The Developer's Handbook to Interactive Multimedia (A Practical Guide for Educational Applications), Kogan Page, London

[7] Gafur, A., 2007, Pengembangan Media Pembelajaran, Universitas Negeri Yogyakarta, Yogyakarta

[8] Lemay, L., Duff, J. M., Mohler, J. L., 1997, Desain Grafik dan Halaman Web, PT. Elex Media Computindo, Jakarta.

[9] Suyanto, M., 2004. Analisis dan Desain Aplikasi Multimedia Untuk Pemasaran. Andi Offset, Yogyakarta.

[10] Sukarjo, 2005, Evaluasi Pembelajaran, Bahan Ajar Mata Kuliah Evaluasi Pembelajaran Prodi Teknologi Pendidikan. 